Lowe, W. J. and J. P. van BUIJTENEN (1989): The incorporation of early testing procedure into an operational tree improvement program. Silvae Genetica 38 (5-6): 243-250.

Magnussen, S. and C. W. Yeatman (1989): Predictions of genetic gains from various selection methods in open pollinated Pinus banksiana progeny sites. Silvae Genetica 39: 140-153.

McKeand, S. E. and F. E. BRIDGwater (1986): When to establish advanced generation seed orchards. Silvae Genetica 35: 245-247.

MCKEAND, S. E. (1988): Optimum age for family selection for growth in genetics tests of Loblolly pine. Forest Science 34: 400-411.

Mulin, T. J., E. G. Morgenstern, Y. S. Park and D. P. FOWLER (1992): Genetic parameters from clonally replicated tests. Canad. J. For. Res. 22, 1: 24-36.

PAWARAYI, I. Z. (1993): Genetic parameters and selection indices for a population of Pinus elliottii Engelm. var elliottii. $\mathrm{Ph}$. D. thesis, Linacre College, Oxford University.

RIEMENSCHNEIDER, D. E. (1988): Heritability, age-age correlations, and inference regarding juvenile selection in jack pine. Forest Science 34: 1076-1082.

RIKLI, M. (1909): Die Arve in der Schweiz. Denkschrift d. Schweizer naturf.Gesellschaft 44, 455p.

SAMUEL, C. J. A. (1991): The estimation of genetic parameters for growth and stem-form over 15 years in a diallel cross of Sitka spruce. Silvae Genetica 40 (2): 67-72.

SCHAFFER, H. E. and R. A. UsAnis (1969): General least squares analysis of diallel experiments: a computer program-DIALL. Genetics Dept. Res. Report 1, North Carolina State University, $61 \mathrm{p}$.
SNyDER, E. B. and G. NAMKoONG (1978): Inheritance in a diallel crossing experiment with longleaf pine. U.S. For. Serv., South For. Exp. Stn., Res. Pap. SO-140.

TAUER, C. G. and R. W. McNeW (1985): Inheritance and correlation of growth of Shortleaf pine in two environments. Silvae Genetica 34, 1: 5-11.

VASQUEZ, J. and W. S. DvoraK (1996): Trend in variance and heritabilities with stand development of tropical pines. Can. J. For. Res. 26: 1473-1480.

White, T. L., G. R. Hodge and G. L. Powell (1993): An advanced-tree improvement plan for slash pine in the southeastern United States. Silvae Genetica, 42: 359-371.

Wilcox, M. D. (1976): Applications of the diallel cross in the breeding of radiata pine. New Zealand For. Serv., For. Res. Inst., Genetics and Tree Improvement Report No. 74, 66 p.

WRIGHT, J. W. (1959): Species hybridization in the white pines. Forest Science, Vol. 5, 3: 210-222.

XIANG, B., B. LI and F. IsIK (2003a): Time trend of genetic parameters in growth traits of Pinus taeda L. Silvae Genetica 52 (3-4): 114-121.

Xiang, B., B. Li and S. McKeand (2003b): Genetic gain and selection efficiency of loblolly in three geographic regions. Forest. Science 49: 196-208.

XIE, C.-Y. and C. C. YING (1996): Heritability, age-age correlation and early selection in lodgepole pine. Silvae Genetica 45: 101-107.

YInG, C. C., C. Thompson and L. Herring (1989): Geographic variation, nursery effects and early selection in lodgepole pine. Can. J. For Res. 19: 832-841.

ZoBEL, B. and J. TALBERT (1984): Applied forest tree improvement. John Wiley and Sons, New-York, 505 p.

\title{
Clonal fertility variation and its effects on the effective population size in the seed orchard of dioecious species, Fraxinus rhynchophylla
}

\author{
By KYu-Suk KANG*) and CHANG-Soo KIM \\ Division of Tree Breeding, Korea Forest Research Institute, Suwon 441-847, Republic of Korea
}

(Received 29 $9^{\text {th }}$ August 2011)

\begin{abstract}
The numbers of female and male flowers were assessed in a clonal seed orchard of Fraxinus rhynchophylla for four consecutive years from 2004 through 2007. The female and male flowers of the grafts from 48 clones were counted individually over the crown. Fertility variation was calculated by sibling coefficient that is related to the coefficient of variation in parental flower assessment. Estimated maternal and paternal fertilities were not constant but varied from year to year, and they were also found to be weakly correlated. The effective numbers of clones serving as male and female parents
\end{abstract}

*) Corresponding author: KyU-SuK KANG. Tel. +82-31-290-1102, Fax. +82-31-292-1009. E-mail: kangks@forest.go.kr were calculated from the sibling coefficients of maternity and paternity. We applied two theoretical approaches to estimate the clonal effective population sizes based on 1) fertility variation (i.e., effective number of parents, $N_{e}^{(c)}$ ) and 2) gender balance (effective population size, $\left.N_{e}^{e}\right)$ among parental genotypes. The values of $N_{e}^{(c)}$ were higher in the years with abundant flowering and seed production, while sibling coefficients were lower. On average (pooled), the maternal, paternal and clonal values of $N_{e}^{(c)}$ were calculated to be $17.3,21.0$ and 38.1 respectively. The $N_{e}^{(c)}$ for maternal gamete gene pool was ranged from 9.8 to 16.7 . The values of $N_{e}$ for paternal gamete gene pool were generally higher (ranged from 14.9 to 21.9 ) than those for maternal. When pooled, the $N_{e}$ was 47.2 and the values of $N_{e}$ were higher when the gender ratio was more balanced. An option of equal 
seed harvest might be good to mitigate fertility variation and to improve gene diversity of seeds.

Key words: status number, sibling coefficient, gene diversity, gender balance, equal seed harvest, Fraxinus rhynchophylla.

\section{Introduction}

Establishment of seed orchards is aiming to the production of high genetic quality seed crops that can cover the existing needs and to achievement of high genetic efficiency. The genetic efficiency of seed orchards depends primarily on the genetic value and genetic contribution of clones to the seed crop, the frequency of selfed embryos, and the proportion of embryos fertilized by external pollen (MATYAS, 1991). The efficiency is also described as the degree up to which the parental clones transfer their genetic superiority and diversity to their progenies.

The maintenance and utilization of the high level of gene diversity is a major concern in the seed orchard programs. As seed orchards become a predominant seed source for broadleaved species, the breeding system of the individual species attracts more scientific and managerial attention, as it may impact the orchard merit (ADAMs and KunZE, 1996).

The orchard goals can be reached only if several prerequisites are met (CHAISURISRI and EL-KASSABY, 1993). One of the requirements is that the orchard clones contribute equally to their offspring as male and female parents. In real conditions, however, this is rarely the case (MUONA and HARJU, 1989; KANG and LINDGREN, 1998). Thus, lack of the above requirement leads to the reduction of the effective population size and the increase of genetic relatedness (KJÆR, 1996; KANG and LINDGREN, 1999).

Status number is half of the group coancestry that is expressed the accumulation of group coancestry (LINDGREN and MULLIN, 1998). Effective number of clone is described how many sibs occurred due to the variation of contribution among clones (KANG and LINDGREN, 1999). Effective population size and status number have been used for monitoring taking into account what is mainly considered as variation in gender and fertility between orchard genotypes (FRANKEL and Soule, 1981; KJÆR and WELLENDORF, 1997).

Evaluating the effectiveness of female and male flower function in a wind-pollinated clonal seed orchard requires a standard measure on the relative probability of cross-pollination between all possible pairs of parents (El-KASSABY and REYNOLDS, 1990). Maternal and paternal reproductive success can be assessed by the proportion of female and male flowers produced by each parent that correlates highly with the number of sound seeds produced (KJÆR and WELLENDORF, 1997). Field counts of female and male flowers can serve as rudimentary estimates of potential clonal female and male gamete contributions and hence fertility.

Fraxinus rhynchophylla is distributed at slopes, along rivers and roadsides throughout China, Japan, Korea and Russia. Trees may reach 20 meters of height and flowers are dioecious, opening with leaves. Pistillate flowers lax with tubular calyx, staminate flowers congested with cupular calyx and samara is spatulate with decurrent wing. The produced wood is good for making furniture, baseball bat, and bark is used for medicine; syringin production, anti-inflammatory, febricide, antidiarrhea and antileukorrhea diseases (LEE, 1980; WILLIS, 1985; YANG et al., 2010). A breeding program of F. rhynchophylla in Korea was initiated in 1950s with plus-tree selection from natural stands. Grafted scion materials were produced and used to establish the clonal seed orchards.

The objectives of this study are 1) to assess the flower production and the number of clones contributing as male and female parents in the clonal seed orchard of Fraxinus rhynchophylla, 2) to calculate clonal fertility variation estimated from the variation of flower production among orchard parents, 3) to estimate the effective number of parents and the effective population size, based on the fertility variation and the gender balance, respectively. Gene diversity in the seed crop, as well as the effect of pollen contamination on the quality of the produced seed are discussed together with management measures that should be followed in the Fraxinus rhynchophylla seed orchard.

\section{Materials and Methods}

\section{Seed orchard and flowering assessment}

The study was carried out in the clonal seed orchard of Fraxinus rhynchophylla, operated by the Korea Forest Research Institute and located at Hwasung (lat. $36^{\circ} 30^{\prime} \mathrm{N}$, long. $126^{\circ} 20^{\prime} \mathrm{E}$, alt. $50 \mathrm{~m}$ ). The location of seed orchard establishment was selected, so that it could be isolated from the naturally occurring stands of the species (Fig. 1). The seed orchard was established in 1992 and comprises 48 clones originating from plus trees. The design of the orchard was completely random, and grafts were two years old at the time of establishment and were planted at spacing $5 \times 5 \mathrm{~m}$ in 2 ha area. Even if no thinning was applied up to date, the overall survival of the grafted material was 90 percent in 2004 .

The seed orchard covers an area of 2 ha and the clones are represented by 1 to 24 ramets, while the total number of trees in the seed orchard was 720. The numbers of female and male flowers were counted separately for each individual tree in the seed orchard in mid-May for four consecutive years from 2004 through 2007. Rate of pollen contamination could not be considered as fixed, while it varied from year to year due also to the limited number of ash trees surrounding the seed orchard. So, pollen contamination was not taken into account in this study.

\section{Fertility estimation}

The numbers of female and male gametes produced by an individual are considered to indicate maternal and paternal fertility, respectively. Expected total fertility can be estimated as the average of maternal and paternal fertility. Fertility variation can be described by sibling coefficient (KANG and LINDGREN, 1999) that is the probability of two genes taken from the gamete gene 


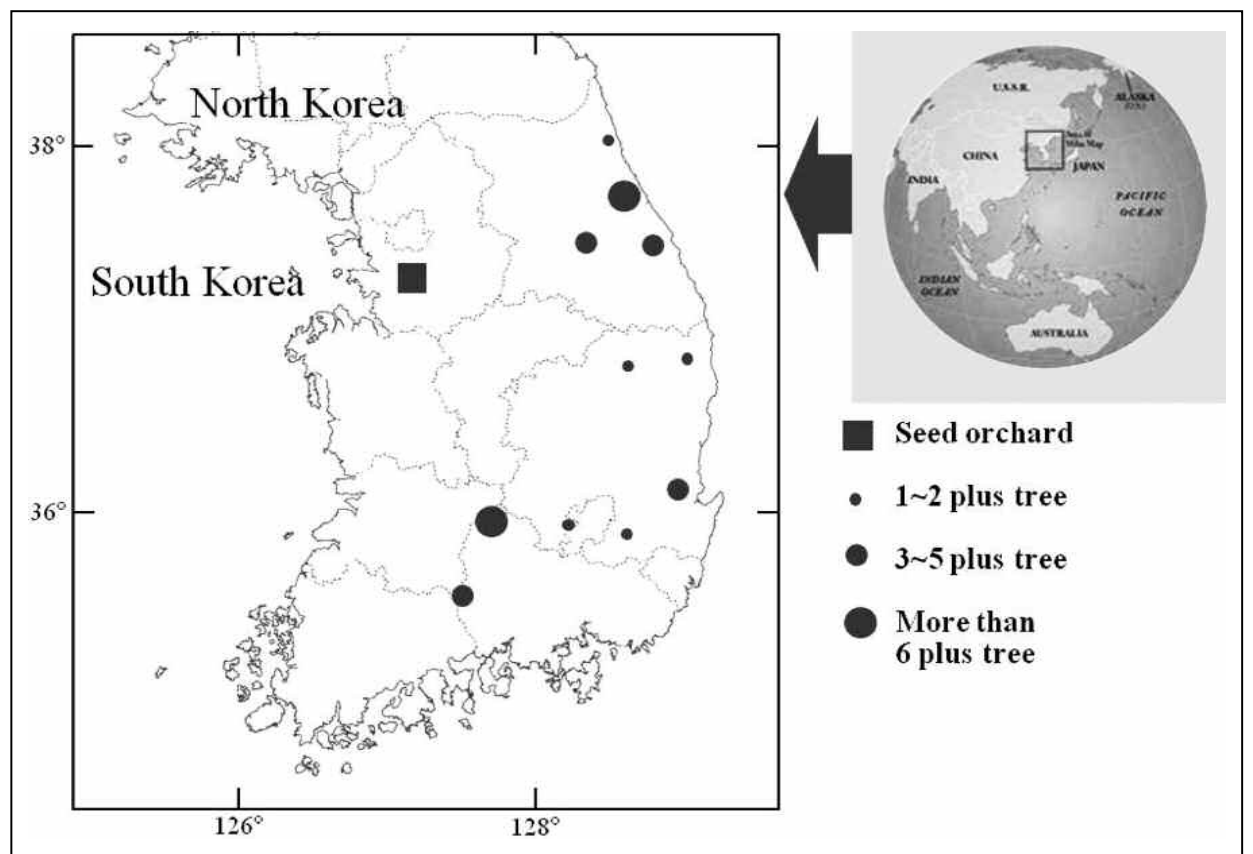

Figure 1. - Location of a clonal seed orchard of Fraxinus rhynchophylla and the origin of its clones.

pool to originate from the same parent. This parameter was compared under the assumption that all clones contribute as parents to the same number of offspring.

The sibling coefficient $(\Psi)$ is related to the coefficient of variation $(\mathrm{CV})$ in parental fertility (KANG and LINDGREN, 1998; 1999). The sibling coefficient for the parental fertility can be divided into maternal sibling coefficient $\left(\psi_{m}\right)$ and paternal sibling coefficient $\left(\psi_{p}\right)$ as

$$
\begin{aligned}
& \psi_{m}=N_{m} \sum_{i=1}^{N_{m}} m_{i}^{2}=C V_{m}^{2}+1 \text { and } \\
& \psi_{p}=N_{p} \sum_{i=1}^{N_{p}} p_{i}^{2}=C V_{p}^{2}+1
\end{aligned}
$$

where $C V_{m}$ and $C V_{p}$ are the coefficients of variation in maternal and paternal fertility, $N_{m}$ and $N_{p}$ are the numbers of female and male parents, and $m_{i}$ and $p_{i}$ are the maternal and paternal contributions of the $i$-th clone, respectively.

Total fertility variation $(\Psi)$ in an orchard is calculated in the case of that there is no contamination from alien pollen (KANG and LINDGREN, 1999; NIKKANEN and RUOTSALAINEN, 2000),

$$
\begin{aligned}
\Psi & =N \sum_{i=1}^{N} F_{i}{ }^{2}=N \sum_{i=1}^{N}\left(\frac{m_{i}+p_{i}}{2}\right)^{2} \\
& =0.25\left(\psi_{m}+\psi_{p}\right)+0.5
\end{aligned}
$$

where $F_{i}^{2}$ is the total fertility of $i$-th clone, and $m_{i}$ and $p_{i}$ are the maternal and paternal contributions of the $i$-th clone, respectively. $N$ is the census number of parents in the seed orchard.

Equal seed harvest is often proposed to control and mitigate the effect of unbalanced contribution among parents in stands and seed orchards (KANG and LINDGREN, 1999; BILA, 2000). Under the equal seed harvest assumption, the maternal fertility is kept constant $\left(\psi_{m}=1\right)$. Thus, the sibling coefficient $\left(\Psi_{\mathrm{e}}\right)$ depends only on the paternal fertility variation and formula (2) can then be re-written as

$$
\Psi_{\mathrm{e}}=\frac{\psi_{p}+3}{4}
$$

\section{Effective population size by fertility variation}

Effective numbers of female $\left[N_{e(m)}\right]$ and male parents $\left[N_{e(p)}\right]$ were calculated from the sibling coefficients of maternal $\left(\psi_{m}\right)$ and paternal $\left(\psi_{p}\right)$ fertility variation, while clonal effective parent number $\left[N_{e}^{(c)}\right]$ was estimated from the total fertility variation $(\Psi)$ as (see KANG and LINDGREN, 1999),

$$
N_{e(m)}=\frac{N_{m}}{\psi_{m}}, N_{e(p)}=\frac{N_{p}}{\psi_{p}}, N_{e}^{(c)}=\frac{N}{\Psi}
$$

Herewith, $N_{m}$ and $N_{p}$ are the numbers of female and male parents and $N$ is the census number of parents in the seed orchard. Relative effective number of parents $\left(N_{r}\right)$ is the inverse of the sibling coefficient (i.e., $\left.N_{r}=1 / \Psi\right)$. The above parameters were also estimated for the case of equal seed harvest.

\section{Effective population size by gender ratio}

The effective population size by gender ratio was estimated based on the number of female and male parents (FrANKel and Soule, 1981) as,

$$
N_{e}=\frac{4 N_{f} N_{m}}{N_{m}+N_{f}}
$$

The results were then compared with the effective population size by fertility variation. 


\section{Results}

\section{Flower production}

Female and male flower production in the clonal seed orchard of $F$. rhynchophylla fluctuated over the years of the study and reached their peaks during 2004 with clonal average values as high as $3,384( \pm 1,757.3)$ and $3,911( \pm 2,011.3)$ for mean number of female and male flowers respectively, while the lowest average values were estimated in 2006 (Fig. 2).

There was also a variation of flower production between genders (Fig. 2). Twenty-one out of the orchards' 48 clones were identified as female parents and twenty-seven clones as male parents. Nineteen among the 21 female parents were consistent female flower producers across the study period. On the individual trees, the higher proportion of male than female was found to be $52 \%$ and about $7 \%$ of the grafts did not produce any flowers.

The $C V$ value of female parent in the good flowering year (0.519 in 2004) was lower than the one estimated for the poor flowering year (0.744 in 2006). This means that fertility is more similar among clones in the good flowering years than in the poor ones. Also, the difference of fertility variation between genders was more pronounced in poor flowering years than in good ones (Fig. 2).
The sibling coefficient of maternal fertility ranged from 1.27 in a good flowering year to 2.14 in 2007 (pooled across years 1.21). The sibling coefficient values of maternal fertility were always higher than those estimated for paternal fertility (Table 1).

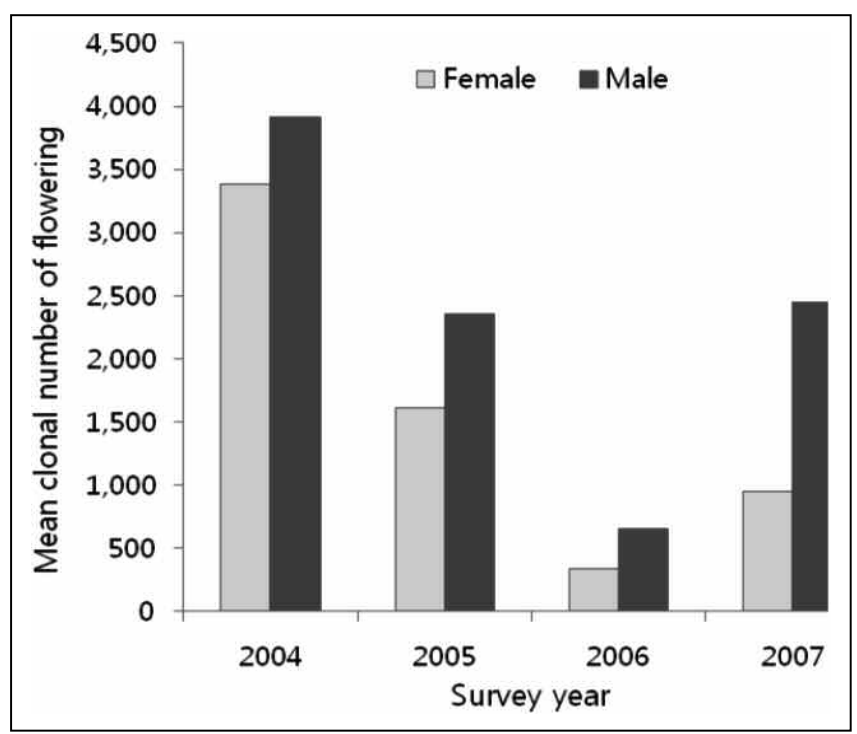

Figure 2. - The mean clonal production of female and male flowers for four consecutive years in a clonal seed orchard of Fraxinus rhynchophylla.

Table 1. - Sibling coefficient ( $\psi_{m} \& \psi_{p}$ ), effective parent number $\left[N_{e(m)} \& N_{e(p)}\right]$ and relative effective parent number $\left[N_{r(m)} \& N_{r(p)}\right]$ for maternal and paternal gamete gene pool over the four consecutive years of the study.

\begin{tabular}{|c|c|c|c|c|c|c|c|c|c|c|}
\hline & \multicolumn{4}{|c|}{ Female parents } & \multirow[b]{2}{*}{ Pooled } & \multicolumn{4}{|c|}{ Male parents } & \multirow[b]{2}{*}{ Pooled } \\
\hline & 2004 & 2005 & 2006 & 2007 & & 2004 & 2005 & 2006 & 2007 & \\
\hline$\psi_{m}^{*} \& \psi_{p}^{*}$ & 1.27 & 1.26 & 1.55 & 2.14 & 1.21 & 1.26 & 1.23 & 1.33 & 1.82 & 1.28 \\
\hline$N_{c(m)} \& N_{c(p)}$ & 16.5 & 16.7 & 13.5 & 9.8 & 17.3 & 21.4 & 21.9 & 20.3 & 14.9 & 21.0 \\
\hline$N_{r(m)} \& N_{r(p)}$ & 0.79 & 0.80 & 0.64 & 0.47 & 0.82 & 0.79 & 0.81 & 0.75 & 0.55 & 0.78 \\
\hline
\end{tabular}

${ }^{*} m$ and $p$ represent female and male parents, respectively.

Table 2. - Sibling coefficient $(\Psi)$, clonal effective parent number $\left[N_{e}^{(c)}\right]$ and relative effective parents $\left(N_{r}\right.$ values for the four successive years of the study, estimated for varying clonal female and male clonal fertilities and for equal seed harvest, which assumes that maternal fertility is constant and equal to one.

\begin{tabular}{|c|c|c|c|c|c|c|c|c|c|c|}
\hline & \multicolumn{5}{|c|}{$\begin{array}{c}\text { Variation in both maternal and paternal } \\
\text { fertility }\end{array}$} & \multicolumn{5}{|c|}{$\begin{array}{l}\text { Maternal Fertility constant } \\
\text { (cqual seed harvest) }\end{array}$} \\
\hline & 2004 & 2005 & 2006 & 2007 & Pooled & 2004 & 2005 & 2006 & 2007 & Pooled \\
\hline$I^{\prime} \& \Psi_{L^{\prime}}$ & 1.28 & 1.26 & 1.47 & 2.01 & 1.26 & 1.07 & 1.06 & 1.08 & 1.20 & 1.07 \\
\hline$N_{c}^{(c)}$ & 37.5 & 38.1 & 32.7 & 23.9 & 38.1 & 45.0 & 45.4 & 44.4 & 39.9 & 44.8 \\
\hline$N_{r}$ & 0.78 & 0.79 & 0.68 & 0.50 & 0.79 & 0.94 & 0.95 & 0.92 & 0.83 & 0.93 \\
\hline
\end{tabular}


Table 3. - Effective number of female parents $\left(N_{m}\right)$ and male parents $\left(N_{p}\right)$ and effective population size $\left(N_{e}\right)$ by sex ratio in a seed orchard of Fraxinus rhynchophylla.

\begin{tabular}{|c|c|c|c|c|c|c|c|c|c|c|}
\hline & \multicolumn{2}{|c|}{2004} & \multicolumn{2}{|c|}{2005} & \multicolumn{2}{|c|}{2006} & \multicolumn{2}{|c|}{2007} & \multicolumn{2}{|c|}{ Pooled } \\
\hline & 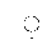 & 8 & p & $\dot{s}$ & 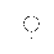 & $\hat{\theta}$ & Y & 8 & 9 & 3 \\
\hline$N_{m} \& N_{p}$ & 21 & 27 & 21 & 26 & 20 & 25 & 19 & 26 & 21 & 27 \\
\hline$N_{c}$ & \multicolumn{2}{|c|}{47.3} & \multicolumn{2}{|c|}{46.5} & \multicolumn{2}{|c|}{44.4} & \multicolumn{2}{|c|}{43.9} & \multicolumn{2}{|c|}{47.2} \\
\hline
\end{tabular}

\section{Effective population size}

The effective number of parents was mirrored to the sibling coefficients (Table 1), but not synchronized with the $C V \mathrm{~s}$ of clonal flower production. The maternal and paternal effective numbers were highest in 2005 and lowest in 2007 , while both years were characterized by intermediate flower production. When the flowering data were pooled, the relative effective number of parents was $82 \%$ for female parents and $78 \%$ for male parents (Table 1).

The lowest effective number of parent was estimated for 2007 that was an intermediate flowering year. When maternal and paternal fertility varied, the clonal effective number of parent was ranged from 38.1 to 23.9 (Table 2). Under the assumption of equal seed harvest, if equal number of seeds was collected from each clone (i.e., maternal fertility constant), then the sibling coefficient would decrease and the clonal effective number of parents would increase (Table 2).

There were 48 clones in total; 21 female and 27 male parents in the clonal seed orchard of $F$. rhynchophylla. All clones produced flowers in the good flowering year (2004) (Table 3). However, a few individual did not produce flowers in specific years of the study $(2005,2006$

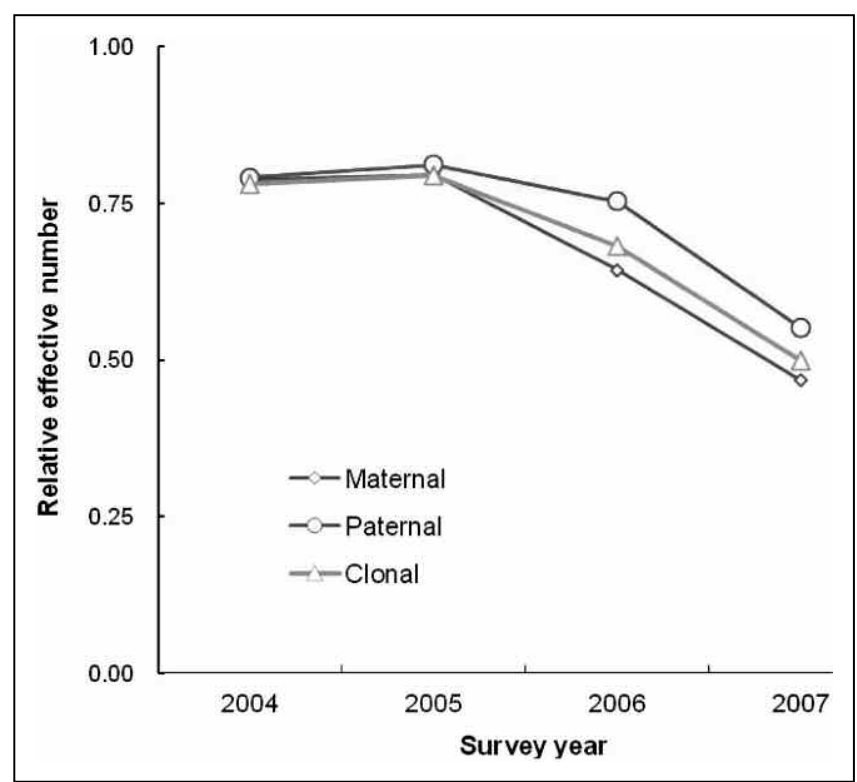

Figure 3. - The relative effective number of female, male and clonal parents for the four years of the study in the $F$. rhynchophylla clonal seed orchard. and 2007), and this would cause the distortion of sexual contribution among clones.

Based on the sex ratio, the clonal effective population size ranged from 47.3 in 2004 to 43.9 in 2007. This result showed the same trend across years as the effective number of parents estimated according to their fertility variation, but the clonal effective population size by gender ratio values were much higher than those estimated for clonal effective number of parents (Table 2 and 3 ).

The relative effective number of maternal, paternal and clonal parents for the studied years were high when the flowering was abundant (2004) (Fig. 3). The seed production was high in 2004, moderate in 2005 and 2007, no seeds were found to be collected in the poor flowering year (data not shown).

\section{Discussion}

Theory on fertility variation among seed orchard clones was formulated considering maternal $\left(\psi_{m}\right)$ and paternal $\left(\psi_{p}\right)$ fertility variation. The correlation between maternal and paternal fertilities was not considered because the studied species, Fraxinus rhynchophylla is a dioecious species (cf., KANG and EL-KASSABY, 2002). Fertility variation is described by the sibling coefficient $(\Psi)$, describing how much fertility varies among parents as the increase of the probability that sibs occur compared to the situation where fertility is equal across the population (KANG and LINDGREN, 1999).

If there is equal fertility among clones, the effective number of parents equals to the census number; the population is ideal and the progeny are distributed in a Poisson distribution (KImURA and CROw, 1963). The $N_{e}^{(c)}$ depends only on the fertility variation among clones and does not depend on how parents are related or inbred (e.g., selfing is regarded as producing two offsprings).

The values of $N_{e}$ were higher than those of $N_{e}^{(c)}$ (Tables 2 and 3). When pooled, the $N_{e}$ was estimated to be 47.2. Thus, the amount of random genetic drift in the seed orchard of 48 clones is equal to the one that would have been recorded in an ideal population consisting of 23.6 maternal and 23.6 paternal (balanced sex ratio) randomly mating clones. But, this estimation is made under the assumption that the female and male parents contribute equally to next generation (FRANKEL and Soule, 1981). 
If an equal amount of seed was harvested from each female parent then the sibling coefficient would decrease and the effective number of parents would increase when compared to the collection of the whole seed crop that incorporates the female and male fertility variation among different genotypes.

Mixing seed crops of different years is an effective management strategy for enhancing effective population sizes (BILA, 2000; KAMALAKANNAN and VARGHESE, 2008). If seeds from different seed production years are mixed, the fertility variation could be considerably reduced, as it was also revealed from the pooled effective population size values estimated in the present study.

Effective population size as a parameter of genetic diversity of the seed orchard output is an important indicator of orchard functioning. It is determined by the variation of male and female contributions of parental genotypes, influenced by the variation in gamete production, reproductive phenology and pollen dispersal (GÖMÖRY et al., 2008; EL-KASSABY and REYNOLDS, 1990). Therefore, reproductive output such as fertility variation, phenology, pollen contamination should be considered for the accurate estimation of effective population size.

Sexual allocation in fertility would also be one of the considerations in the effective number estimation (SAVOLAINEN et al., 1993). The relative effective number of parents in the moderate flowering year (2007) was lower than that in the poor flowering year (2006). This result could be the outcome of the distorted gender ratio during the moderate flowering year, compared to the poor flowering one.

\section{Acknowledgements}

This study is supported by the Korea Forest Research Institute and authors thank to colleagues from the Korea Seed and Variety Center for their cooperation in the collection of flowering data.

\section{Literature cited}

AdmAs, G. W. and H. A. KunZE (1996): Clonal variation in cone and seed production in black spruce seed orchards and management implications. For. Chron. 72: 475-480.

BILA, A. D. (2000): Fertility variation and its effect on gene diversity in forest tree populations. Ph.D. thesis. Swedish University of Agricultural Sciences, Umeå, Sweden.

Chaisurisri, K. and Y. A. El-Kassaby (1993): Estimation of clonal contribution to cone and seed crops in a Sitka spruce seed orchard. Ann. Sci. For. 50: 461-467.

Gömöry, D., R. LONGAUer, L. PAUle and R. BRUChániK (2008): Factors affecting effective population size estimation in a seed orchard: a case study of Pinus sylvestris. In: LINDGREN, D. (Editor), Proceedings of a Seed Orchard conference. Umea, 26-28 September, 2007. p. $242-253$.
KAMALAKANNAN, R. and M. VARGHESE (2008): Mixing of seed crops from different years is an effective management strategy for enhancing effective population sizes in Eucalyptus seedling seed orchard crops. In: LindGREN, D. (Editor), Proceedings of a Seed Orchard conference. Umea, 26-28 September, 2007. p. 104-113.

El-Kassaby, Y. A. and S. ReYnolds (1990): Reproductive phenology, parental balance, and supplemental mass pollination in a Sitka spruce seed orchard. For. Ecol. Manage. 31: 45-54.

Frankel, O. H. and M. E. Soule (1981): Conservation and evolution. Cambridge University Press. p. 31-77.

KANG, K. S. and D. LINDGREN (1998): Fertility variation and its effect on the relatedness of seeds in Pinus densiflora, $P$. thunbergii and $P$. koraiensis clonal seed orchards. Silvae Genet. 47: 196-201.

KANG, K. S. and D. LINDGREN (1999): Fertility variation among clones of Korean pine and its implications on seed orchard management. For. Genet. 6: 191-200.

KANG, K. S. and Y. A. EL-Kassaby (2002): Considerations of correlated fertility between genders on genetic diversity: Pinus densiflora seed orchard as a model. Theor. Appl. Genet. 105(8): 1183-1189.

KIMURA, M. and J. F. CROW (1963): The measurement of effective population number. Evolution, 17: 279-288.

KJÆR, E. D. (1996): Estimation of effective population number in a Picea abies (Karst.) seed orchard based on flowering assessment. Scand. J. For. Res. 11: 111-121.

KJÆR, E. D. and H. WELLENDORF (1997): Variation in flowering and reproductive success in a Danish Picea abies (Karst.) seed orchard. For. Genet. 4: 181-188.

LEE, C. B. (1980): Flora of Korea. Hyang-moom sa. Seoul. pp.990.

LinDGREN, D. and T. J. MulLin (1998): Relatedness and status number in seed orchard crops. Can. J. For. Res. 28: 276-283.

MATYAs, C. (1991): Seed orchards. In: Genetics of Scots pine. Joint edition with Elsevier Science Publishers, Amsterdam. Akademiai Kiado, Hungary. p. 125-145.

MUONA, O. and A. HARJU (1989): Effective population size, genetic variability, and mating systems in natural stands and seed orchards of $P$. sylvestris. Silvae Genet. 38: $221-228$.

NIKKANEN, T. and S. RUOTSALAINEN (2000): Variation in flowering abundance and its impact on the genetic diversity of the seed crop in a Norway spruce seed orchard. Silva Fen. 34: 205-222.

Savolainen, O., K. KarkKainen, A. HaRJu, T. NikKanen and M. RUSANEN (1993): Fertility variation in P. sylvestris: a test of sexual allocation theory. Am. J. Bot. 80: 1016-1020.

Willis, J. C. (1985): A dictionary of the flowering plants and ferns. $8^{\text {th }}$ edition. Cambridge University Press. New York. pp. 1311.

YANG, E-J., S-I. KIM, HN-Y. K, D-S. LeE, J-W. LeE, Y-S. KIM, Y-H. SEONG and K-S. Song (2010): Syringin from stem bark of Fraxinus rhynchophylla protects $\mathrm{A} \beta_{(25-35)}$-induced toxicity in neuronal cells. Archives of pharmacal research 33(4): 531-538.

Herausgeber: Johann Heinrich von Thünen-Institut. Bundesforschungsinstitut für Ländliche Räume, Wald und Fischerei. Schriftleitung: Institut für Forstgenetik, Sieker Landstrasse 2, D-22927 Grosshansdorf Verlag: J. D. Sauerländer's Verlag, Berliner Strasse 46, D-63619 Bad Orb Anzeigenverwaltung: J. D. Sauerländer's Verlag, Bad Orb

Gesamtherstellung: PPPP Norbert Wege e.K., Gladenbach — Printed in Germany. 